\title{
Vol. 549: 275-288, 2016 \\ Riding the tide: use of a moving tidal-stream habitat by harbour porpoises
}

\author{
Steven Benjamins* ${ }^{*}$ Andrew Dale, Nienke van Geel, Ben Wilson
}

Scottish Association for Marine Science, Oban, Argyll PA37 1QA, UK

\begin{abstract}
Tidal-stream habitats present periodically fast-flowing, turbulent conditions. Evidence suggests that these conditions benefit top predators such as harbour porpoises Phocoena phocoena, presumably allowing them to optimise exploitation of prey resources. However, clear demonstration of this relationship is complicated by the fact that strong tidal flows often occur near-simultaneously across a wide area. The Great Race of the Gulf of Corryvreckan (western Scotland, UK) is a jetting tidal system where high-energy conditions persist across a broad range of tidal phases in a localised, moving patch of water. Porpoises can therefore actively enter or avoid this habitat, facilitating study of their usage of adjacent high- and low-energy environments. The distribution of harbour porpoises was studied using passive acoustic porpoise detectors (C-PODs) deployed on static moorings ( $35 \mathrm{~d}$ ) and on Lagrangian drifters moving freely with the current (up to $\sim 48 \mathrm{~h}$ ). This dual approach provided complementary perspectives on porpoise presence. C-PODs moored in the path of the Great Race registered a significant increase in detections during the passing of the energetic tidal jet. Encounter durations recorded by drifting C-PODs were longer than those recorded by moored C-PODs, suggesting that porpoises tended to move downstream with the flow rather than remaining stationary relative to the seabed or moving upstream. The energetic, turbulent conditions of the Great Race are clearly attractive to porpoises, and they track its movement with time; however, their structured movements in response to the evolving tidal situation cannot simply be represented as a direct relationship between current speed and porpoise presence.
\end{abstract}

KEY WORDS: Phocoena phocoena - Tidal-stream habitats - Drifters - Passive acoustics · Distribution

\section{INTRODUCTION}

Sites where local configurations of topography and coastline cause large tidal flows to pass through narrow straits or around headlands are often referred to as tidal-stream habitats. Flow speeds often exceed $1 \mathrm{~m} \mathrm{~s}^{-1}$ and sometimes reach $4 \mathrm{~m} \mathrm{~s}^{-1}$ or more, resulting in highly energetic conditions (Davies et al. 2012). Several authors have commented on cetaceans such as harbour porpoises Phocoena phocoena, bottlenose dolphins Tursiops truncatus and minke whales Balaenoptera acutorostrata exploiting energetic tidalstream habitats (Johnston et al. 2005a,b, Pierpoint

\footnotetext{
${ }^{*}$ Corresponding author: steven.benjamins@sams.ac.uk
}

2008, Bailey \& Thompson 2010). Ephemeral yet predictable oceanographic structures (e.g. fronts, boils and eddies) may improve foraging opportunities, although other benefits, such as cost-free transport, may also contribute to their appeal (Stevick et al. 2008, Embling et al. 2012, Benjamins et al. 2015, IJsseldijk et al. 2015). In apparent contrast, other studies (Embling et al. 2010, Booth et al. 2013) have indicated that harbour porpoise densities, in particular, are more strongly associated with low-flow habitats, although this may be partially linked to methodological differences. The influence of smallscale, ephemeral flow features on harbour porpoise

() SAMS 2016. Open Access under Creative Commons by Attribution Licence. Use, distribution and reproduction are unrestricted. Authors and original publication must be credited. 
distribution in tidal-stream habitats is increasingly recognised (De Boer et al. 2014, Jones et al. 2014), but it is unclear whether absolute current speed is the most important factor determining porpoise presence within these environments. Studying relationships between cetacean occurrence and strong tidal flows is logistically complex, limiting our current understanding of the precise nature of the drivers behind such relationships (Wilson et al. 2013).

An important consideration when studying the ecology of tidal-stream habitats is the distinction between Eulerian and Lagrangian frames of reference (Batchelor 2000). The former focuses on observing water flowing past a stationary point, while the latter follows a parcel of water moving through space and time. Both perspectives offer insights into how animals use these habitats, particularly whether they position themselves relative to the (stationary) seafloor or a (moving) parcel of water. However, many standard monitoring methods (e.g. line-transect surveys, instrumented moorings) only provide an Eulerian perspective, potentially providing an incomplete picture of habitat usage.

The aims of this study were to combine Eulerian and Lagrangian techniques to explore small-scale spatiotemporal variability in the distribution of vocalising harbour porpoises in relation to tidal currents. The Gulf of Corryvreckan system (comprising the Gulf of Corryvreckan, the Great Race and the northern Sound of Jura in western Scotland; Fig. 1) is a prominent tidal-stream site of recognised conservation significance (JNCC 2014) that provides suitable conditions to study porpoises in this manner. Porpoises are frequently observed here, and anecdotal observations by local tourboat operators suggest that porpoise distribution is influenced by tidal currents
(T. Hill pers. comm.). We studied porpoises using passive acoustic click detectors (C-PODs), which are widely used to investigate spatiotemporal patterns in odontocete occurrence (Castellote et al. 2013, Dähne et al. 2013, Roberts \& Read 2015).

\section{MATERIALS AND METHODS}

\section{Study site}

The Gulf of Corryvreckan is a $1 \mathrm{~km}$ wide tidal strait between the islands of Jura and Scarba (western Scotland; Fig. 1). Differences in tidal amplitude and phase between the Sound of Jura to the east and the Firth of Lorn to the west lead to a surface slope which drives strong tidal flows through the Gulf. Current speeds can exceed $4 \mathrm{~m} \mathrm{~s}^{-1}$ in either direction (UK Hydrographic Office 2008). During the west-flowing (flood) tide, water accelerating through the Gulf is ejected into the Firth of Lorn as a relatively narrow tidal race, known as the Great Race. The Great Race is turbulent, displaying structure on a wide range of scales including eddy instabilities of its flanks and a patchwork of surface structure representing turbulent bursts (boils) and convergences driven by vortices shed from the seabed (Kumar et al. 1998, Stoesser et al. 2008). The Race progressively advances into less energetic waters, reaching a maximum length of $\sim 10 \mathrm{~km}$. Hydrodynamic model studies (Dale et al. 2011) show the Race forming a 'vortex pair' of counterrotating eddies at its advancing head (Fig. 2; Fujiwara et al. 1994, Old \& Vennell 2001, Wells \& van Heijst 2003). These eddies track westwards in deep water $(\sim 200 \mathrm{~m})$ but largely stall as they encounter shoaling topography $(\sim 50 \mathrm{~m})$ southwest of

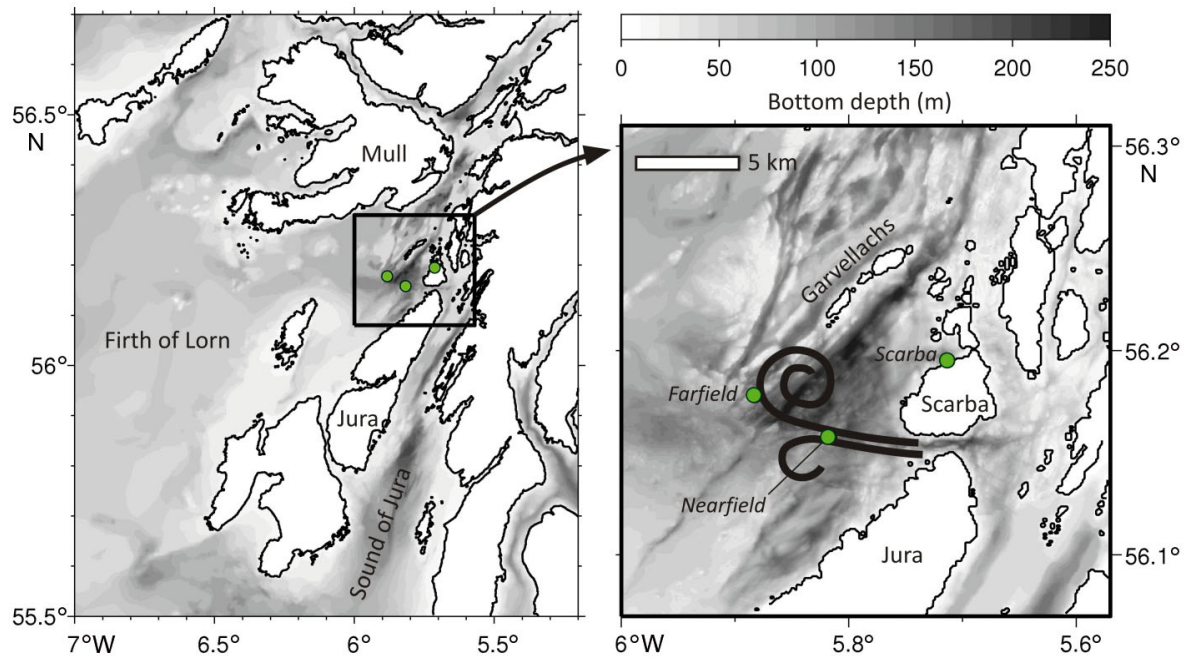

Fig. 1. Study site on the west coast of Scotland, with bottom topography shaded. The Gulf of Corryvreckan runs east-west between the islands of Scarba and Jura. The Nearfield, Farfield and Scarba moorings are shown (in green) relative to the approximate path of the Great Race (in black) 


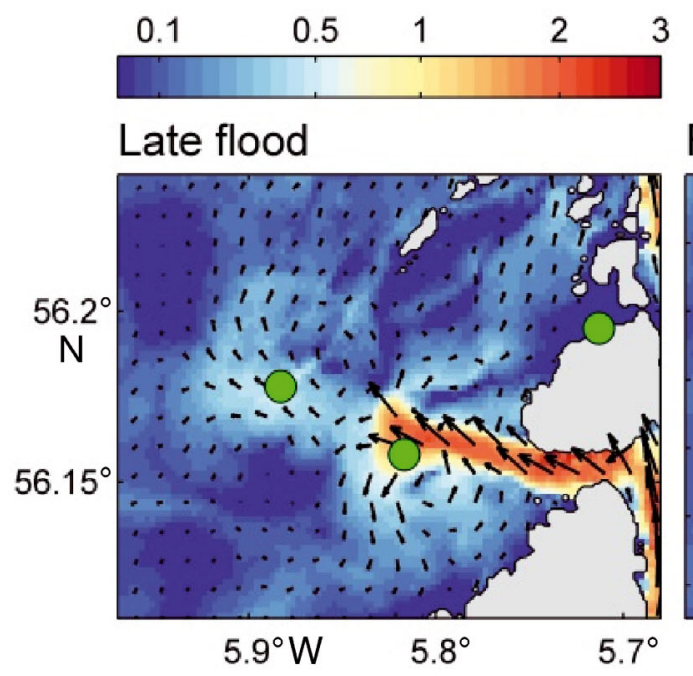

\section{Surface current speed $(\mathrm{m} / \mathrm{s})$}
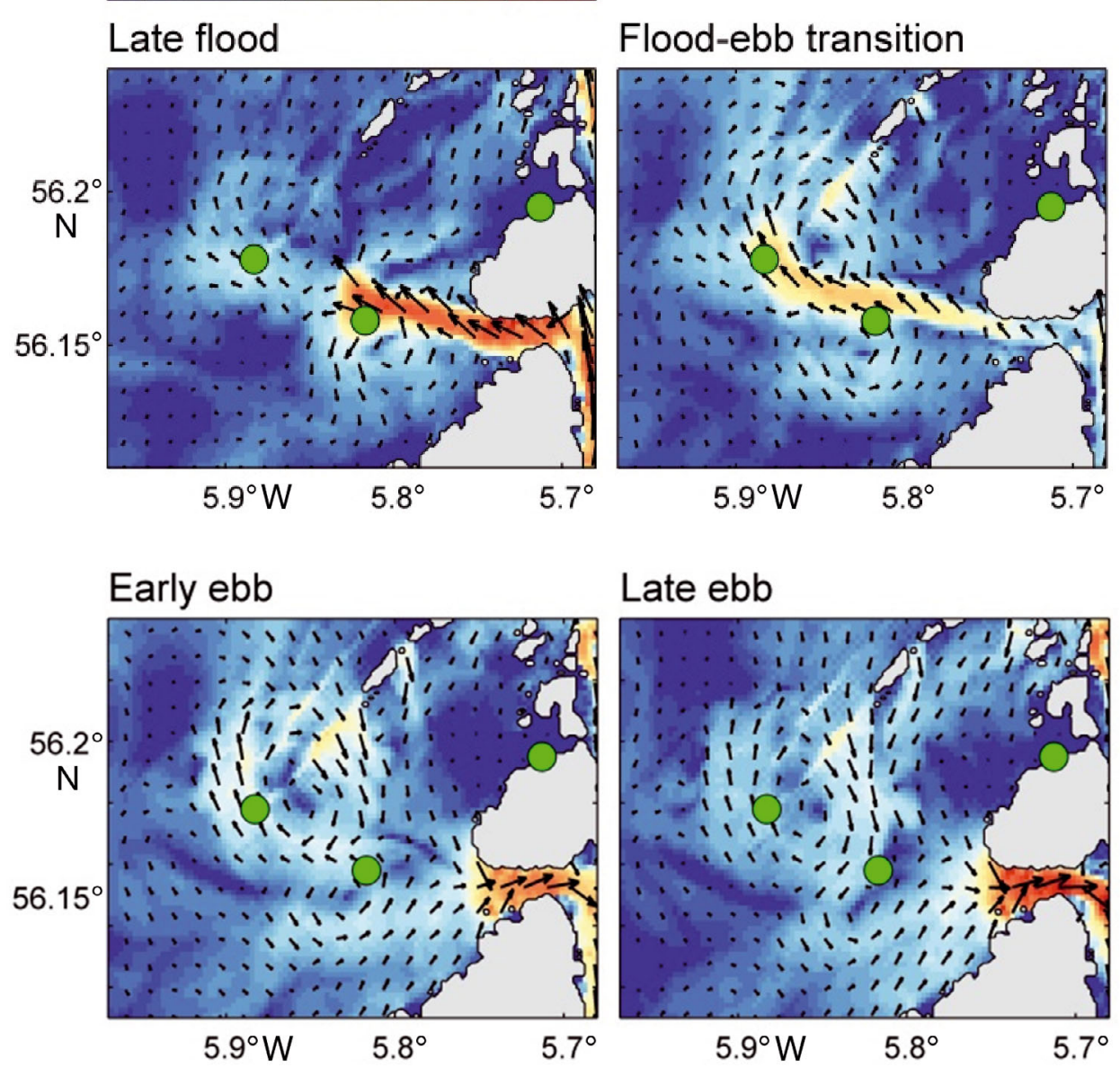

Late ebb

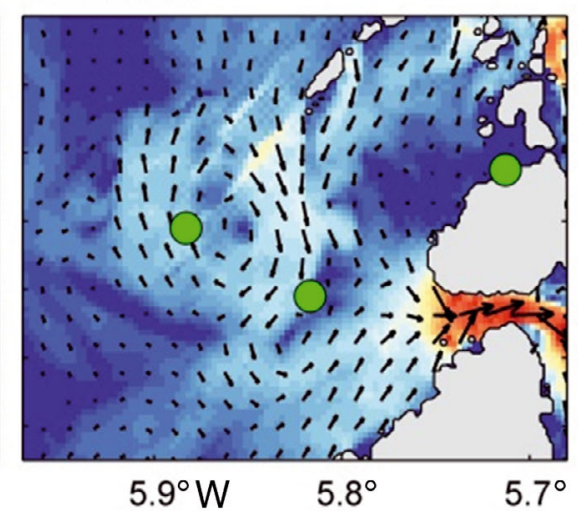

Fig. 2. Surface currents from a hydrodynamic model of the Great Race relative to flood and ebb in the Gulf of Corryvreckan. The interval between panels is $2 \mathrm{~h}$, and they correspond to approximately 67, 125, 183 and 241 tide-degrees relative to low tide in Oban (see 'Materials and methods' for details). Vectors show current direction, and underlying colours show speed. Green discs correspond to mooring locations from Fig. 1

the Garvellach islands (Figs. 1 \& 2). The ejection of energy into open water means that significant flow persists within the Race for longer than within the Gulf of Corryvreckan itself. Approaching slack water in the Gulf, the Great Race eddies are fully developed, and the greatest surface velocities exist in the outer Great Race and over the reef to the southwest of the Garvellachs (Fig. 2). During eastward (ebb) flow in the Gulf of Corryvreckan, the energy within the Great Race gradually decays (Fig. 2). The more constrained environment of the Sound of Jura, to the east, means that the energy of the ebb tide does not persist in the same manner as within the Great Race, so there is an asymmetry in the system in this respect.

For the present study, the key aspect of the Great Race is that the flood tide provides an energetic pulse of water which progressively advances into the more open Firth of Lorn and persists within this large area of open water. However, these conditions could be readily avoided by a mobile animal with an aversion to energetic environments.

The data presented here were gathered in association with the ongoing Great Race project (UK NERC Grant No. NE/H009299/1), focusing on the tidal dynamics of waters to the west of the Gulf of Corryvreckan. C-PODs were deployed on both fixed moorings and on passively drifting buoys (Wilson et al. 2012, 2013). This unusual combination of methods provided an opportunity to explore the influence of tidal flows on the spatiotemporal distribution and movements of harbour porpoises in the Gulf of Corryvreckan system, relative to both the seabed and moving water. 


\section{Moored C-PODs}

Three porpoise click detectors (C-PODs Version 1; Chelonia 2015) were deployed in and around the Great Race from 20 July to 25 August 2011 (Table 1). Fitted with an omnidirectional hydrophone, C-PODs use waveform characteristics to identify odontocete echolocation clicks among broadband pulsed sounds of 20 to $160 \mathrm{kHz}$, also recording time, duration, centre frequency, loudness, inter-click interval and bandwidth of each received click. C-PODs log a record of each detection event rather than record actual sounds, thereby reducing data storage requirements. Detection ranges vary according to ambient noise levels but have been estimated at several hundred metres (Dähne et al. 2013). Odontocete echolocation signals are identified by automated post-processing train detection and classification algorithms. C-PODs have sufficient battery and memory capacity to remain deployed and continuously logging for up to 3 mo.

In this study, 2 C-PODs were moored in the path of the Great Race jet at $\sim 7$ and $\sim 11 \mathrm{~km}$ from the Gulf of Corryvreckan, respectively ('Nearfield' and 'Farfield' moorings). The Farfield mooring also contained an upward-looking acoustic Doppler current profiler (ADCP) to measure flow speeds (pinging every $4 \mathrm{~s}$; 15 pings used to obtain a 1 min average) mounted above the C-POD to minimise interference. Nearfield and Farfield C-PODs were deployed $\sim 15 \mathrm{~m}$ above the seabed in waters of 114 and $95 \mathrm{~m}$ depth, respectively. A third C-POD ('Scarba' mooring) was deployed $\sim 5 \mathrm{~km}$ north of the Great Race off Scarba $\sim 15 \mathrm{~m}$ above the seabed in water of $\sim 60 \mathrm{~m}$ depth. No
ADCP data were collected from either the Nearfield or Scarba moorings. Although the Scarba site was adjacent to a narrow tidal channel flowing in approximate synchrony with the Gulf of Corryvreckan, flows were much less strong and the site could therefore serve as a reference site (Fig. 1).

\section{Drifting C-PODs}

Although passive acoustic detectors are typically moored for long-term high-resolution coverage, this approach can cause problems in tidal-stream habitats (Wilson et al. 2013), including generation of flow noise as water moves past the detector $(\mathrm{Au} \&$ Hastings 2008, Bassett et al. 2010). Therefore, additional C-PODs were attached to Lagrangian drifters (Wilson et al. 2013). Advantages of this approach are that (1) flow noise is reduced as detectors are effectively stationary relative to the surrounding water; (2) drifting detectors provide increased spatial coverage $_{i}(3)$ logistics of repeatedly deploying/retrieving drifters from small boats are relatively straightforward. Earlier studies revealed that this approach represented an effective way to study porpoises in energetic tidal-stream habitats (Wilson et al. 2012, 2013).

Two drifter designs were used: Type 1 drifters were deployed during 20-21 June 2011 and 18-20 August 2012, and Type 2 drifters were deployed during 15-17 October 2013. These were fundamentally similar but kept the C-POD at slightly different depths below the surface (Type 1 at $2 \mathrm{~m}$; Type 2 at $5 \mathrm{~m}$ ). Type 1 drifters transmitted their locations for tracking using GSM mobile phone signals. Due to signal coverage limitations, the Type 2 drifter was redesigned to broadcast positions via the Iridium $^{\mathrm{TM}}$ satellite network. Drifters were deployed for $\geq 24 \mathrm{~h}$ before repositioning or recovery. Drifters were released either within the Gulf of Corryvreckan, to capture westward flow within the main jet $(2011,2013)$, or near the Garvellachs to sample far-field water movements (2012, 2013); no drifters were deployed near the Scarba mooring, as the Great Race Project did not focus on this area. 


\section{Analysis}

Upon retrieval, raw data from C-PODs were processed using the CPOD.exe software (v.2.040, Chelonia 2015). Only click trains classified as 'Moderate-' or 'High-quality porpoise click trains' were used in subsequent analyses (Carlström 2005). A randomly selected subsample of $5 \%$ of the raw data associated with potential detections from moored C-PODs was checked visually to ensure that there were no false positives; all potential detections from drifting CPODs were checked in this manner. Suspect detections were removed from further analysis.

All C-POD data were analysed at a resolution of both individual click trains and porpoise-positive minutes (PPMs). PPMs were also arranged into encounters, here defined as $\geq 2$ click trains separated from other encounters by $\geq 10$ min (cf. Carlström 2005). Encounter numbers and durations are influenced by numerous factors, including porpoise echolocation beam characteristics, number of echolocating porpoises within detection range at any given time and ambient noise. Comparing encounter durations between different moored C-PODs, and between moored vs. drifting C-PODs, allowed additional assessment of porpoise usage of the Gulf of Corryvreckan system.

A background current that is comparable to or greater than swimming speed has the potential to bias measures of porpoise presence. In a rapid flow, the rate at which animals are swept past a fixed detector increases, although each individual is within detection range for a shorter period of time than in weaker flow. If porpoises echolocate at a constant rate, the rate at which click trains are detected provides an unbiased measure of the density of porpoises (more individuals but fewer click trains per individual). PPMs, however, are biased because the increase in the rate at which animals are swept past the detector leads to an increased chance that a given minute will be a PPM.

Moored C-POD data were analysed using descriptive circular statistics (Raleigh's test for circular uniformity; Watson-Williams test to compare sites) as well as the nonparametric Kruskal-Wallis test and contingency table analyses (Zar 1999). Independence between moorings was assumed given intermooring distances of $>4 \mathrm{~km}$. Drifting C-POD data were matched to GPS coordinates at a temporal resolution of whole minutes to calculate drift speeds and map distances travelled. C-POD data were not used where corresponding GPS data were unavailable due to signal coverage limitations. Following these results, both moored and drifting C-POD data were further analysed using logistic generalised additive models (GAMs) and generalised estimation equations (GEEs) in order to investigate the relative importance of different covariates on porpoise detections, based on methods described in greater detail by Pirotta et al. (2011). Data from each moored CPOD (Nearfield, Farfield and Scarba) were modelled independently, while all drifter data from each deployment (2011, 2012 and 2013) were combined by year. Further details of the GAM-GEE modelling approach and results are provided in the Supplement, available at www.int-res.com/articles/suppl/ m549p275_supp.pdf.

Data were aggregated by tidal cycle to study tidal effects on porpoise click train detections. The duration of each tidal cycle was derived from tidal predictions for the nearby port of Oban $(\sim 33 \mathrm{~km})$ based on harmonic analysis (POLTIPS-3 ${ }^{\mathrm{TM}}$ tidal prediction software). Times within each cycle were then assigned a tidal phase angle relative to low water $\left(0^{\circ}=360^{\circ}=\right.$ low tide at Oban). Tides in this area are semidiurnal (average duration $12.4 \mathrm{~h}$ ), although individual cycles vary in duration according to the stage of the springneap cycle, such that $1^{\circ}$ of tidal phase (or tidedegree) represents 2.0 to 2.2 minutes. Importantly, although low tide in Oban was used as a reference, the timing of low water varies markedly across the area of interest, and lateral tidal flows, rather than tidal heights per se, are relevant here. Peak flood (westward) flow within the Gulf of Corryvreckan occurs approximately $38^{\circ}$ after low tide at Oban, and peak ebb (eastward) flow occurs approximately $218^{\circ}$ after low tide at Oban.

To avoid prematurely filling C-PODs' memory over extended deployments, an upper limit of 4096 clicks $\mathrm{min}^{-1}$ is normally set. High ambient noise levels can cause this limit to be reached before the end of a given minute, leading to cessation of monitoring until the start of the next minute (Booth 2016). Given comparatively brief deployment periods, memory capacity problems were unlikely, so all C-PODs were programmed with a limit of 65536 clicks $\min ^{-1}$ to maximise porpoise detection probability under high ambient noise conditions.

\section{RESULTS}

\section{Moored detections}

Moored C-PODs were deployed for approximately $36 \mathrm{~d}$, equivalent to 71 consecutive semidiurnal tidal cycles. Click train and encounter data are sum- 
marised in Table 1. A total of 6 minutes (2 from Nearfield, 3 from Farfield, 1 from Scarba) were discarded due to C-POD data writing errors. Despite concerns about high ambient noise levels, the standard detection limit of 4096 clicks min $^{-1}$ was exceeded in only 489 minutes $(0.3 \%$ of total; Table 1$)$; $54 \%$ of these were detected at the Scarba mooring, including 2 containing click trains. This suggested that the impact of high ambient noise levels at all 3 moored locations was comparatively limited, but that Scarba experienced noisier conditions, potentially due to larger volumes of vessel traffic. The 2 click trains identified among noisy minutes at Scarba were assessed visually and confirmed as likely genuine porpoise click trains. No obvious interference by the ADCP was apparent in the Farfield C-POD dataset.

All C-PODs regularly registered click trains throughout their deployments. Click train detection rates were significantly different between sites (KruskalWallis-test: $H=18.852, \mathrm{p}<0.01$ ), with highest detection rates at the Scarba site and lowest at the Farfield site (Table 1). The greatest number of individual encounters $(n=412)$ was recorded at the Nearfield site (Table 1). Most encounters (>88\%) lasted $\leq 5 \mathrm{~min}$.
The C-POD on-board tilt sensor measured instrument deflection from vertical (degrees; $0^{\circ}=$ vertical). C-POD deflection varied strongly with tidal phase (Fig. 3A), due to knock-down by tidal currents. Greatest deflections were observed at Nearfield and Farfield moorings during the flood tide, when the Great Race was predicted to flow most strongly. An average lag of $\sim 80$ min was observed between the peak deflection from vertical between Nearfield and Farfield, indicating the later arrival of the Great Race at the Farfield site (Fig. 3A). ADCP data from the Farfield site confirmed a positive correlation between C-POD deflection and current speed (ANOVA: $F=$ 3084.058; $\mathrm{df}=1851 ; \mathrm{p}<0.001)$. Farfield average CPOD deflection increased approximately linearly from $<20^{\circ}$ at speeds $<0.5 \mathrm{~m} \mathrm{~s}^{-1}$, to $>60^{\circ}$ at 0.5 to $2 \mathrm{~m}$ $\mathrm{s}^{-1}$; small sample size $(\mathrm{N}=7)$ precluded firm conclusions during greater speeds but suggested a deflection to $>80^{\circ}$ at 3 to $3.5 \mathrm{~m} \mathrm{~s}^{-1}$. As Nearfield and Farfield moorings were of similar construction, repeated similar C-POD deflections of $>80^{\circ}$ observed at the Nearfield site were assumed to correspond to flow speeds $\geq 3 \mathrm{~m} \mathrm{~s}^{-1}$. Although the Scarba mooring setup allowed more C-POD movement, C-POD deflection varied least at Scarba, indicating that conditions at this site were less energetic (Fig. 3A).

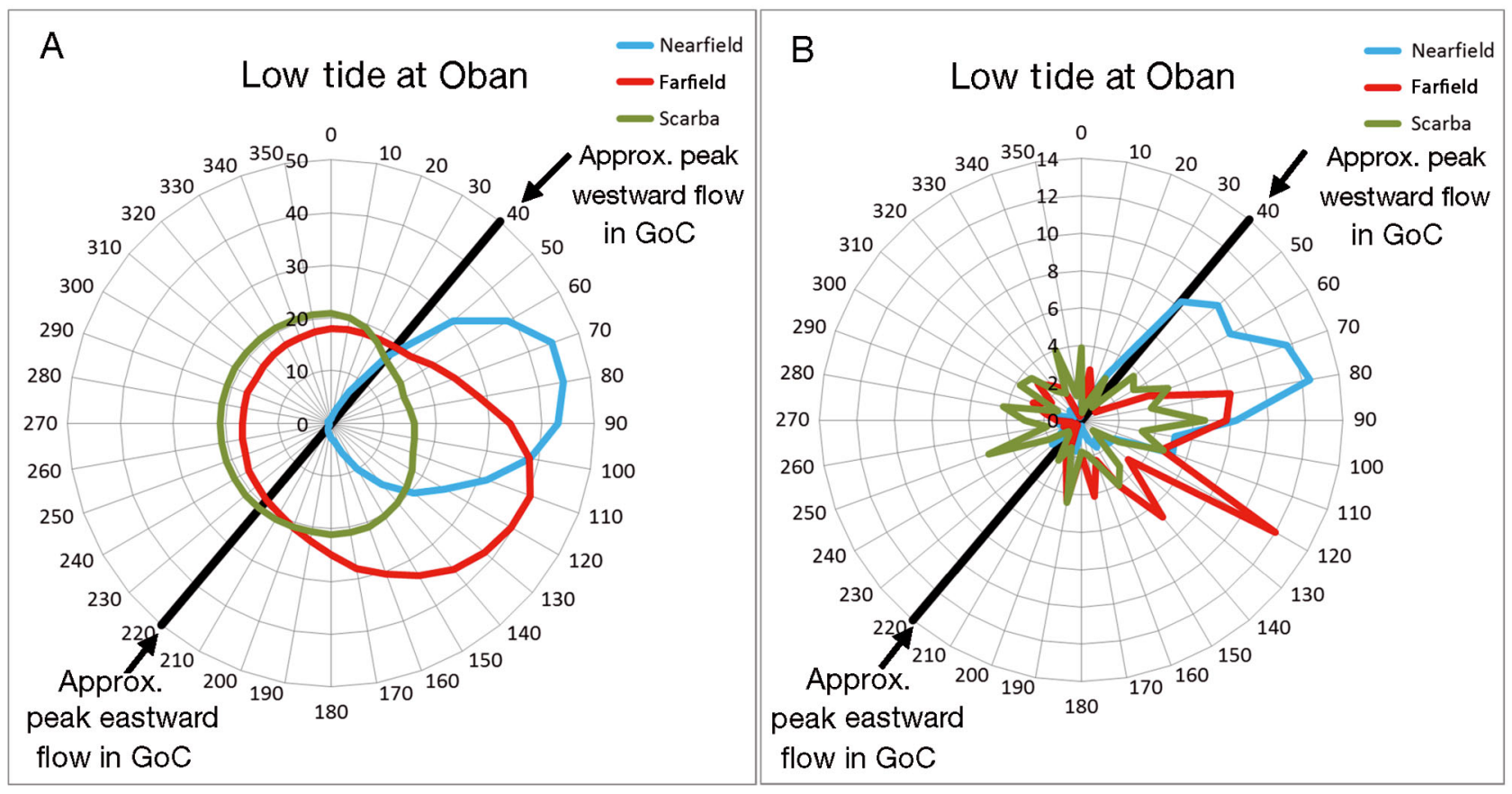

Fig. 3. (A) Average deflection from vertical $\left(0^{\circ}=\right.$ vertical) of moored passive acoustic porpoise detectors (C-PODs) during the entire deployment across the tidal cycle $\left(0^{\circ}=360^{\circ}=\right.$ low tide at Oban, in $10^{\circ}$ increments). (B) Percentage of total harbour porpoise Phocoena phocoena click trains detected at the 3 sites, by tidal phase. Approximate peak westward (flood) and eastward (ebb) flow within the Gulf of Corryvreckan $(\mathrm{GoC})$ are indicated. Note the phase lag in both C-POD deflections and click train detections linked to differing arrival time of the Great Race at the Nearfield and Farfield sites 
PPMs were typically based on only a few click trains per minute (maximum of 42, at Scarba); 86 to $95 \%$ of PPMs at moored C-PODs were based on $\leq 5$ click trains $\mathrm{min}^{-1}$. PPM identification probability is increased if multiple click trains per minute are received. However, fast movement of echolocating porpoises in tidal flows may limit the number of click trains received by moored C-PODs, thereby affecting PPM detection rates and encounter lengths. The relationship between flow speed and click train detection rates could only be directly assessed for the Farfield site, where click trains were identified at speeds up to $1.5 \mathrm{~m} \mathrm{~s}^{-1}$. However, C-POD deflection angle could be used as a proxy for flow speeds at the Nearfield site. Based on Farfield ADCP data, click trains were significantly more likely to be associated with higher flow speeds (0.5-1.5 $\left.\mathrm{m} \mathrm{s}^{-1}\right)$ associated with the Great Race than with more commonly observed background flow speeds of $<0.5 \mathrm{~m} \mathrm{~s}^{-1}\left(\chi^{2}=149.317\right.$, $\mathrm{df}=3$, $\mathrm{p}<0.001)$. For both Farfield and Nearfield sites, the greatest proportion of porpoise click trains (normalised by effort) occurred at C-POD deflections of 40 to $60^{\circ}$, assumed to correspond to flow speeds of approximately 1 to $2 \mathrm{~m} \mathrm{~s}^{-1}$.

The distribution of click trains across the tidal cycle was significantly non-uniform at all 3 sites (Raleigh's test for circular uniformity; $\mathrm{p}<0.001$ ), with click trains strongly associated with particular tidal phases at all sites (Fig. 3B). The 3 sites also differed significantly from each other in terms of which tidal phase was associated with peak click train detection rates (Watson-Williams test: $F=1850.38 ; F_{\text {critical }}=3.84 ; \mathrm{p}<$ $0.001)$. At the Nearfield site, more click trains were observed earlier in the tidal cycle (mean \pm SD tidal phase $=103 \pm 70$ tide-degrees) than at the Farfield site (mean tidal phase $=153 \pm 83$ tide-degrees). A second (minor) peak occurred at the Farfield site at $\sim 250$ to 330 tide-degrees. Scarba click train data were distributed more evenly across the tidal cycle (mean tidal phase $=175 \pm 101$ tide-degrees) .

\section{GAM-GEE modelling of moored detections}

Details of GAM-GEE models of the moored detections are available in the Supplement. Overall, the models, using binary porpoise presence/absence data as the response variable, confirmed the outcomes of earlier analyses. Tidal phase angle, diel hour and tidal cycle were significant covariates for all 3 locations, although their relative significance varied (Figs. S1-S3 in the Supplement at www.intres.com/articles/suppl/m549p275_supp.pdf). Results from confusion matrices indicated that the Farfield final model worked best in terms of predicting presence and absence of porpoises, followed by the Nearfield final model. The Scarba final model did less well in correctly predicting porpoise absence than the others (see Supplement for details).

\section{Drifter detections}

In 2011 and 2013, drifters were released in the Gulf of Corryvreckan and carried westward by the flood tide within the developing Great Race (Fig. 4). Drifters were sometimes 'spun out' of the Great Race into eddies forming on its flanks or head and subsequently re-joined the main flow. The most consistent eddy was a clockwise circulation that developed to the north of the Great Race $(\sim 5 \mathrm{~km}$ south of the Garvellachs; Fig. 2); eddies to the south tended to be weaker and less persistent. In 2012 and 2013, drifters released southwest of the Garvellachs provided coverage of waters to the west of Scarba and Jura during eastward (ebb) flow back through the Gulf of Corryvreckan. Collectively, the 3 deployment campaigns sampled the entire Gulf of Corryvreckan system, including the Great Race jet and its associated eddy fields. Drifter deployment data are summarised in Table 2 and Figs. 4 \& 5. Although the 2013 drifter deployments occurred in October, detection rates were comparable to those obtained in June 2011 (Table 2).

Drifter speed varied considerably within and among individual drifts. Fastest speeds $\left(>4 \mathrm{~m} \mathrm{~s}^{-1}\right)$ were observed within the Gulf of Corryvreckan during both westward and eastward flows. Drifters carried westward by the Great Race could maintain speeds $>2 \mathrm{~m} \mathrm{~s}^{-1}$ as far as $\sim 7 \mathrm{~km}$ from the Gulf of Corryvreckan. Within eddies on the flanks of the Great Race, west of Scarba and south of the Garvellachs, speeds were typically $\leq 0.5 \mathrm{~m} \mathrm{~s}^{-1}$ (Fig. 5). As the tide turned and eddies weakened, drifters eventually entered the wider Firth of Lorn.

Despite extreme flow speeds and turbulence associated with the Great Race, all drifting C-PODs were recovered and functioned throughout. They also proved effective at detecting porpoises and made detections throughout the area across different tidal phases and flow speeds.

Unlike moored C-PODs, the standard detection limit of 4096 clicks min $^{-1}$ was exceeded regularly during several drifter deployments, indicating comparatively high levels of ambient noise (Table 2). This noise could be generated by turbulence (notably in 


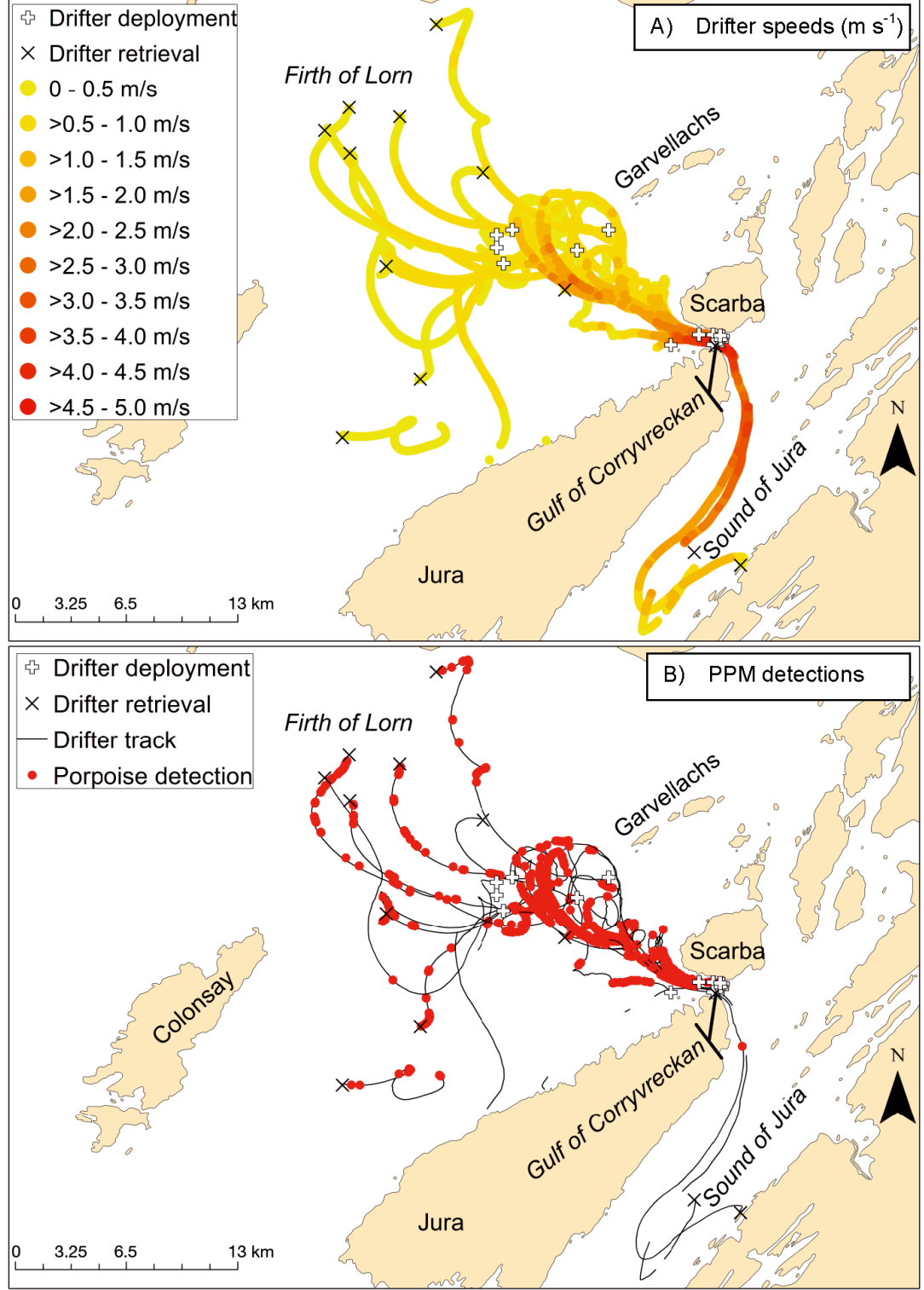

Fig. 4. Combined data from 2011 to 2013 drifting campaigns in the Gulf of Corryvreckan system. (A) Observed drifter speeds. (B) Harbour porpoise Phocoena phocoena detections (PPM: porpoise-positive minute). Gaps in tracks represent periods when position data from Type 1 drifters were unavailable (see 'Materials and methods' for details on drifters)

Table 2. Summary of drifting passive acoustic porpoise detector deployments, by year. Table includes data from 3, 4 and 3 drifters from 2011, 2012 and 2013, respectively; 2013 drifters were deployed twice on consecutive days. PPM: porpoisepositive minute

\begin{tabular}{|c|c|c|c|}
\hline & 2011 & 2012 & 2013 \\
\hline Deployment period & 20-21 Jun 2011 & 18-20 Sep 2012 & $15-17$ Oct 2013 \\
\hline Deployment duration range (hh:mm) & $21: 39-23: 10$ & $22: 40-45: 57$ & $22: 37-23: 58$ \\
\hline No. of minutes exceeding & $12-829$ & $4-652$ & $1-12$ \\
\hline 4096 clicks $\min ^{-1}$ limit ( $\%$ of total) & $(1.3-59.9)$ & $(0.3-48.4)$ & $(0.0-0.4)$ \\
\hline No. of PPMs & $33-160$ & $1-20$ & $155-252$ \\
\hline No. of PPMs within 'noisy' minutes (>4096 clicks min ${ }^{-1}$ ) & $0-7$ & $1-22$ & 0 \\
\hline Mean PPMs $\mathrm{h}^{-1}$ & $1.53-7.12$ & $0.04-0.44$ & $3.29-4.67$ \\
\hline Mean no. of click trains $\mathrm{PPM}^{-1}$ & $2.7-6.8$ & $2.6-9.0$ & $2.7-5.2$ \\
\hline Mean no. of click trains $\mathrm{h}^{-1}$ & $4.1-71.9$ & $0.4-2.2$ & $4.7-25.2$ \\
\hline Total no. of porpoise encounters & $4-14$ & $1-14$ & $14-22$ \\
\hline Encounter duration (min) & $1-124$ & $1-20$ & $1-82$ \\
\hline
\end{tabular}


the centre of the Great Race), waves breaking nearshore and artificial sound sources (e.g. ships). When checking for false positives, 23 PPMs were considered suspect and were discarded from subsequent analyses.

The average click train detection rate across all drifts was very low, 4.13 (95\% CI: 3.93-4.33) click trains $\min ^{-1}$. There was considerable variability in click train detection rates between drifters depending on their location, speed and direction of movement (Figs. 4 \& 5). During the westward flood tide in the Gulf of Corryvreckan and the development of the Great Race, most click trains were detected within these features or adjacent eddies (Fig. 5A,B,G,H), whereas concurrent monitoring of open waters of the Firth of Lorn (as undertaken in 2013) revealed fewer click trains. In contrast, very few click trains were detected near the Gulf of Corryvreckan during eastward ebb flow, with most detected in open waters farther west (Fig. 5C-F). Drifters collectively spent limited time in fast-flowing waters, moving $<0.5 \mathrm{~m}$ $\mathrm{s}^{-1}$ during $>73 \%$ of total deployment time following ejection from the Great Race (Figs. 4 \& 5). However, click train detection rates were higher at speeds $>1 \mathrm{~m}$ $\mathrm{s}^{-1}$ (Fig. 6). Porpoises were detected in flows of up to $2.6 \mathrm{~m} \mathrm{~s}^{-1}$. Although click train detection rates ranged up to 68 click trains PPM $^{-1}$, most (73-95\%) of PPMs detected by drifting $\mathrm{C}$-PODs were based on $\leq 5$ click trains $\min ^{-1}$, comparable to moored C-PODs. There was no obvious relationship between drifting speeds and click train detection rates, whether by PPM or by hour (Table 2), in contrast to the moored C-POD results.

Porpoise encounter durations varied considerably within and between drifter deployments, from $\leq 1 \mathrm{~min}$ to $>2 \mathrm{~h}$ (Table 2). Several long encounters (>60 min) occurred, both within the Great Race and in open waters of the Firth of Lorn. Significant differences in encounter duration were found across moored and drifting platforms $\left(\mathrm{ANOVA}_{i} \mathrm{p}<0.001\right)$, with drifter encounters often lasting considerably longer (mean \pm $\mathrm{SD}=12.0 \pm 18.9 \mathrm{~min}$ ) than those observed by moored C-PODs (Nearfield: $4.4 \pm 6.5$ min; Farfield: $=3.6 \pm$ $4.8 \mathrm{~min}_{\text {; Scarba }}=6.3 \pm 8.5$ min; Fig. 7).
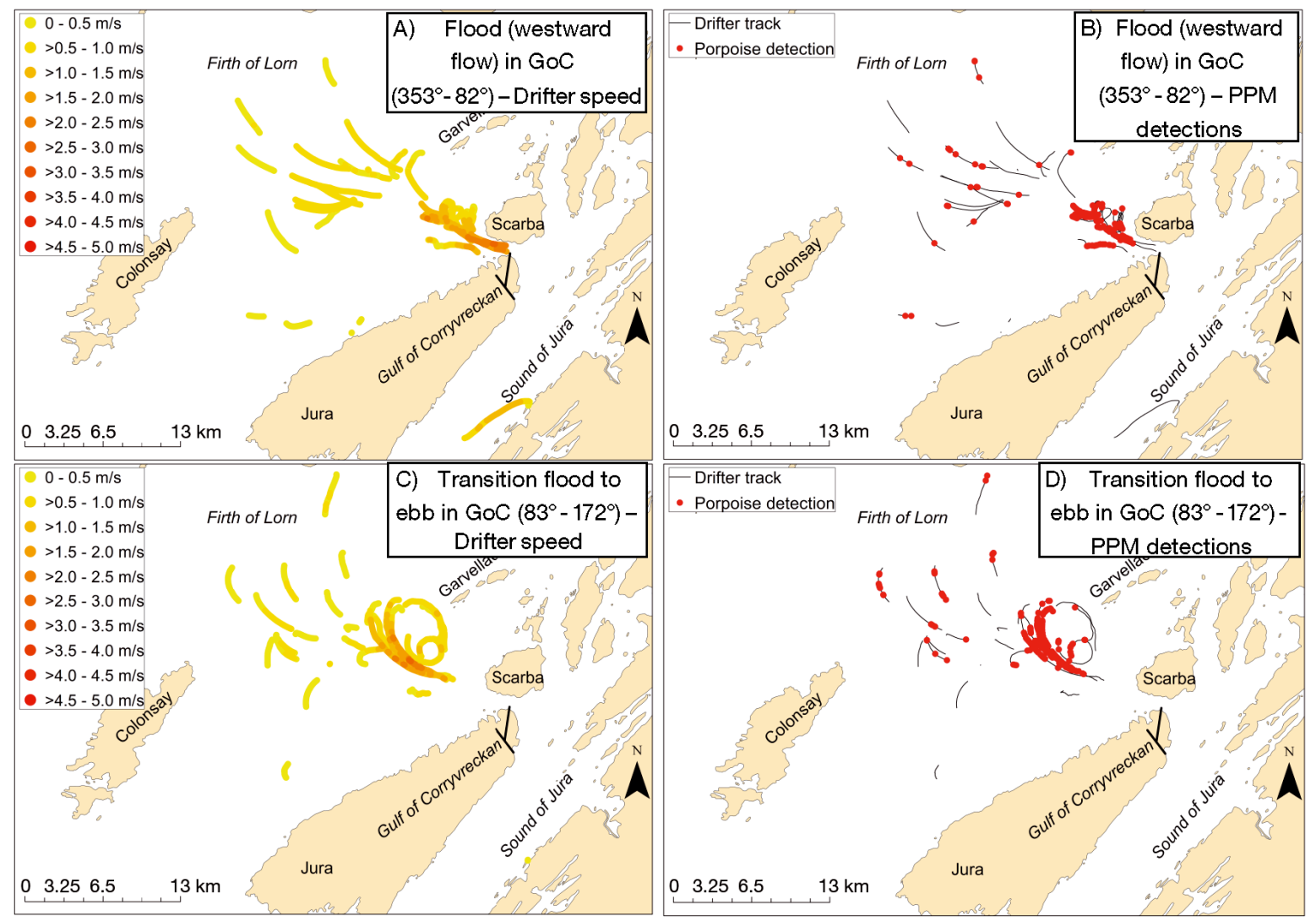

Fig. 5 (Above and following page). Combined data from 2011 to 2013 drifting campaigns in the Gulf of Corryvreckan system. Data aggregated by $90^{\circ}$ of tidal phase, centred upon peak westward (flood) flow within the Gulf of Corryvreckan (GoC) (estimated at $38^{\circ}$ after low tide at Oban). Panels A,B: Flood/peak westward flow; Panels C,D: Transition Flood->Ebb; Panels E,F: Ebb/peak eastward flow; Panels G,H: Transition Ebb->Flood. Panels A, C, E and G represent drifter speeds ( $\mathrm{m} \mathrm{s}^{-1}$ ), while B, D, $\mathrm{F}$ and $\mathrm{H}$ show harbour porpoise Phocoena phocoena detections (porpoise-positive minutes, PPMs) 


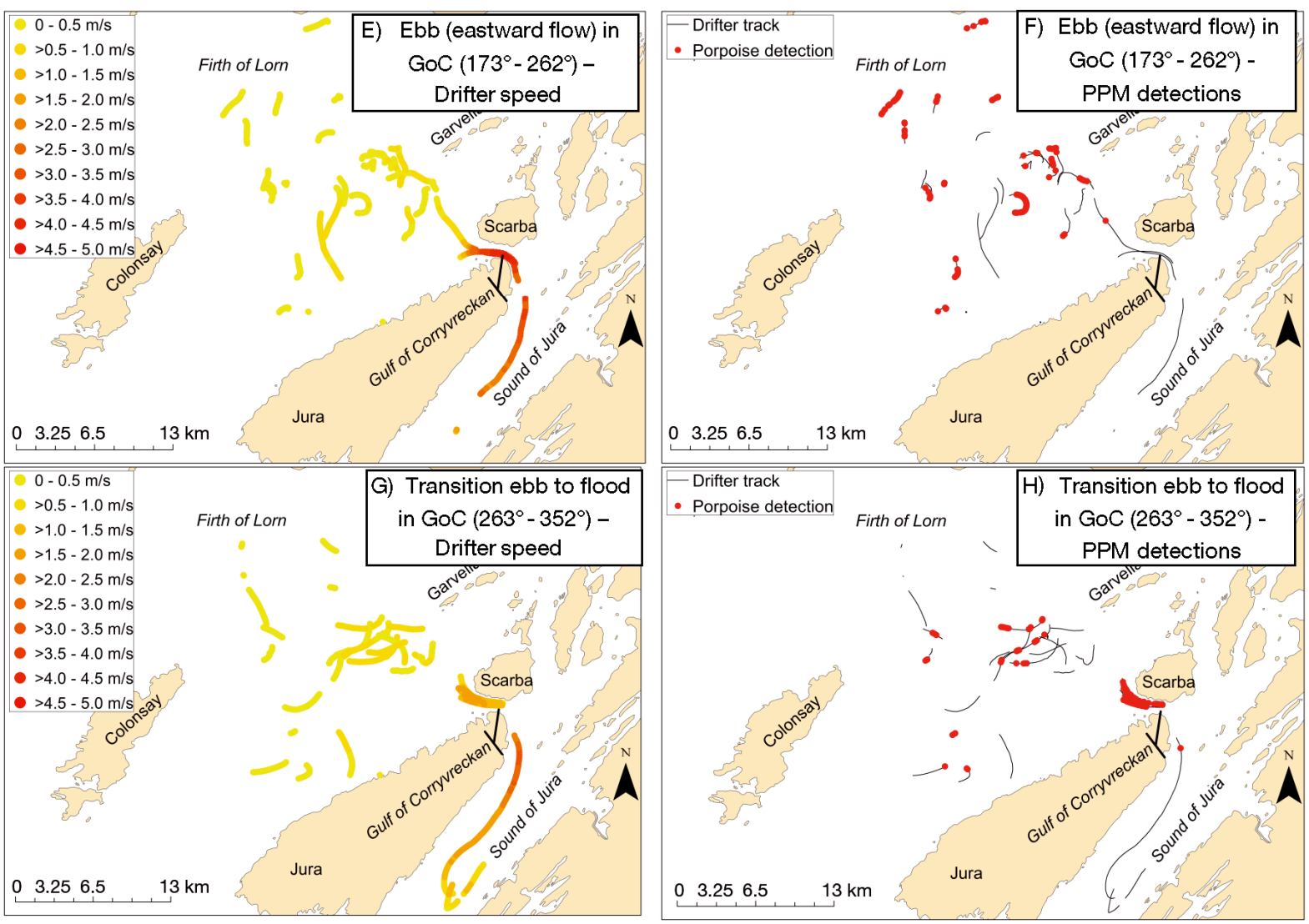

Fig. 5 (continued)

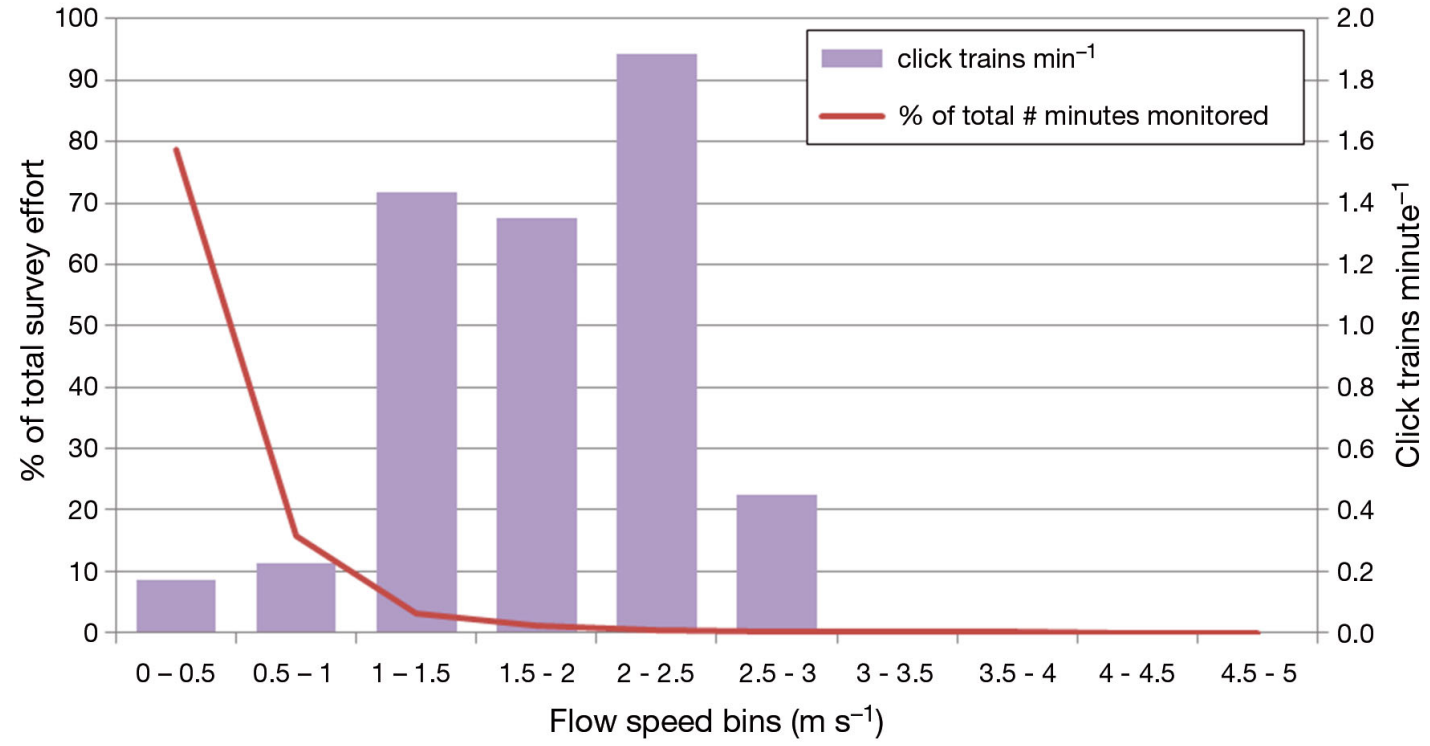

Fig. 6. Proportion of total drifter survey effort (red line) by flow speed ( $0.5 \mathrm{~m} \mathrm{~s}^{-1}$ bins), and harbour porpoise Phocoena phocoena click train detection rates (per minute) in each flow speed bin (purple bars)

\section{GAM-GEE modelling of drifter detections}

Details of GAM-GEE models of the drifter detections are available in the Supplement. We found sig- nificant variability between models in terms of which covariates had a significant influence on the binary response variable (presence/absence of detected echolocation). Model results indicated that drift speed and 


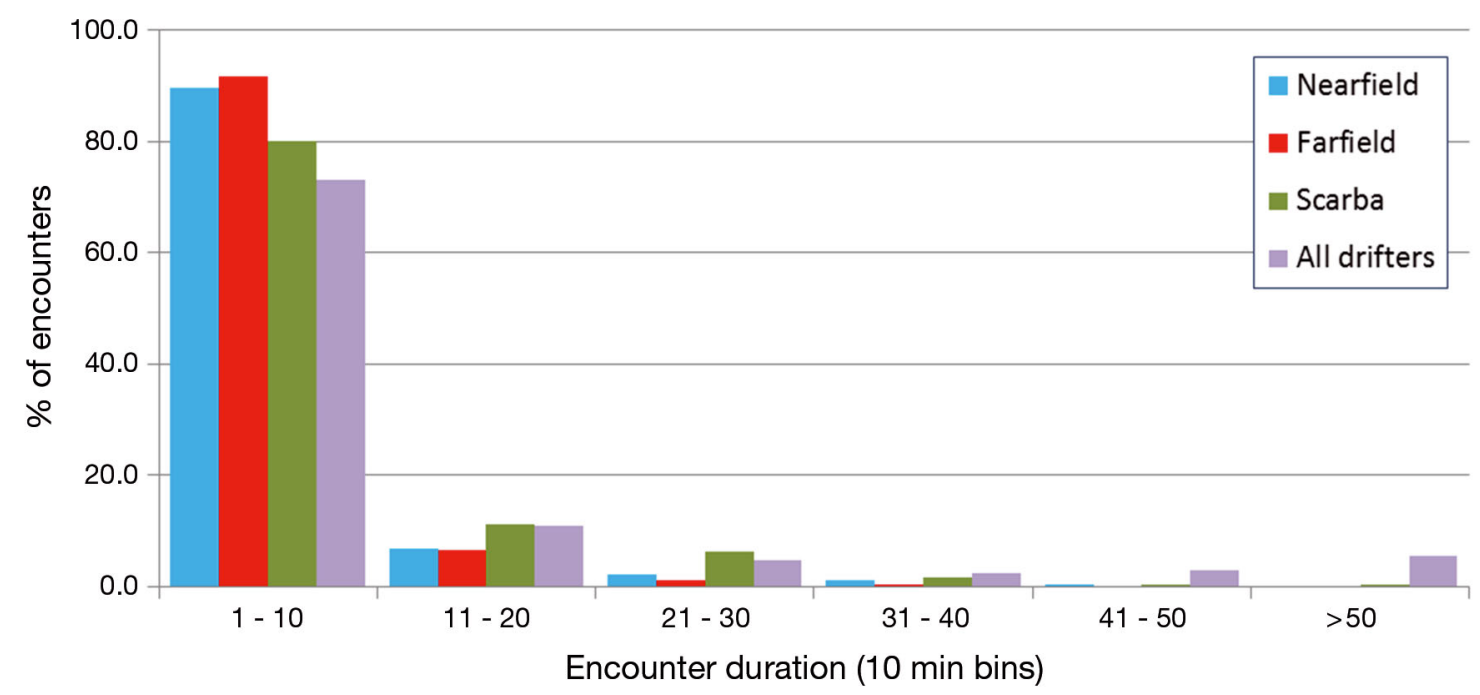

Fig. 7. Summary of harbour porpoise Phocoena phocoena encounter durations (minutes) aggregated in 10 min bins, for all moored sites and all drifters combined. Although brief encounters dominated, drifters observed more long encounters, particularly when compared to the Nearfield and Farfield moorings

tidal phase angle were important covariates during flood tides (2011 and 2013 data) but not during ebb tide (2012 data). The 2013 model incorporated more covariates than the others, possibly due to multiple deployments at comparable tidal phases (3 drifters deployed twice on consecutive days, vs. 3 drifters deployed once each time in 2011 and 2012). It is unclear to what extent variability in initial drifter placement could have influenced the relationships between latitude and/or longitude and porpoise detections.

\section{DISCUSSION}

Our study has illustrated the value of integrating Lagrangian and Eulerian perspectives to investigate small-scale use of energetic tidal-stream habitats by harbour porpoises. Detection of echolocating harbour porpoises in open water to the west of the Gulf of Corryvreckan appeared strongly influenced by tidal flow. At locations in the path of the Great Race, porpoise detections were more frequent when the Great Race and its downstream eddy fields elevated local flow speeds (Figs. 3-5 and see the Supplement). A strong positive relationship was observed between click train detection rates and flow speeds (Farfield site) as well as C-POD deflection angle (Farfield and Nearfield sites), suggesting that porpoise detection rates were correlated with faster currents associated with the Great Race. Moreover, the tidal phase of peak detection rate at the Nearfield mooring occurred approximately 100 minutes earlier than at the
Farfield mooring (Fig. 3B), consistent with porpoises being associated with the energetic pulse of the Great Race as it advanced westwards (see also modelling results in the Supplement). In contrast, the Scarba site, to the north of the Gulf of Corryvreckan system, showed regular and consistent porpoise presence with only limited influence of tidal phase, and the highest detection rate of all moored sites.

High energy in the Great Race persists during slack water in the Gulf of Corryvreckan, and areas of energetic and less energetic waters can be found in relative proximity to one another (within several hundreds of metres to kilometres) across most of the tidal cycle. This contrasts with smaller, more constrained tidal channels (e.g. Wilson et al. 2013), where energetic conditions (ebb and flood) and slack water are relatively synchronous across the system. This complicates efforts to investigate the attractiveness of fast-flowing waters to porpoises in these small sites since many areas are energetic at the same time. With mean swimming speeds of harbour porpoises in the 1 to $2 \mathrm{~m} \mathrm{~s}^{-1}$ range and sprint speeds exceeding $4 \mathrm{~m} \mathrm{~s}^{-1}$ (Westgate et al. 1995, Otani et al. 2000, 2001, Verfuß et al. 2005), porpoises could leave energetic waters within the Gulf of Corryvreckan system should they choose to do so. The association of elevated porpoise detection rates with the most energetic tidal flow within the Great Race suggests active selection of these conditions in preference to the same locations when flows are reduced (Fig. 5). This does not imply that porpoises favour fast flows under all circumstances, as evidenced by the continued regular usage of the adjacent Scarba site. 
Instead, the Gulf of Corryvreckan system might only attract porpoises under certain conditions, or porpoise vocalisation rates might vary in fast-flowing waters. Based on the results presented here, we hypothesize that porpoises spend most of their time in relatively low-energy environments (as exemplified by the Scarba site), but gather at the western entrance to the Gulf of Corryvreckan as the flood tide starts, moving downstream with the energetic waters of the Great Race as it develops. As currents slow down, porpoises are assumed to leave the dissipating remnants of the Race and move elsewhere. The secondary peak in porpoise detections at the Farfield site during ebb did not coincide with increased flow speeds (Figs. 3 \& S2). Such observations might conceivably indicate animals returning towards the Gulf of Corryvreckan in anticipation of the next tidal cycle, but further data are required to verify this speculation.

The complementary Eulerian and Lagrangian perspectives allowed us to explore whether porpoises were actively swimming within the flow or passively carried downstream. The Nearfield and Farfield sites were approximately $4 \mathrm{~km}$ apart, and flow speeds in the area ranged between 1 and $2 \mathrm{~m} \mathrm{~s}^{-1}$ at peak flow (Fig. 4). A porpoise passively carried along within the Great Race would spend approximately 35 to 65 min travelling between the 2 sites. Importantly, the observed average lag of 100 min (Fig. 3B) associated with detections between Nearfield and Farfield sites suggested that, instead of passively drifting downstream, porpoises appeared to be making some headway against the westward current, e.g. through zigzagging or diving (Gordon et al. 2014). Mean encounter duration recorded by drifting C-PODs was considerably longer than recorded by moored C-PODs (Fig. 7), suggesting overall downstream movement (with the drifters), rather than remaining stationary (relative to the seabed) or advancing upstream. In summary, the results indicate that at least some porpoises periodically and repeatedly enter the Great Race and get relocated westward whilst attempting to remain localised within this energetic system, presumably for foraging, before returning to calmer waters.

Drifting C-PODs detected most click trains at flow speeds between 1.0 and $2.0 \mathrm{~m} \mathrm{~s}^{-1}$ (Fig. 6), with click trains detected at speeds up to $2.6 \mathrm{~m} \mathrm{~s}^{-1}$ but not above. These observations are comparable to other tidal-stream sites (e.g. Pierpoint 2008), suggesting that flow speeds of $\sim 2.5$ to $3 \mathrm{~m} \mathrm{~s}^{-1}$ might represent an approximate upper limit for adult harbour porpoises within tidal-stream habitats. The near-complete absence of click trains detected by the drifters in the
Sound of Jura was interesting, although limited research effort in this area to date precluded further investigation and conclusions.

As described in the Supplement, use of GAMGEEs provided broadly comparable results to the preceding analyses, when considered on an individual site or yearly basis. While GAMs allowed the relative significance of different covariates to be determined, the results should be interpreted with care. In particular, each of the partial residual plots included in Figs. S1 to S6 describes progressively less and less residual variability, and should therefore not be considered independently. Moreover, the very different model structures generated by the different drifter datasets indicate considerable interlinked variability that may be difficult to express within the present limited set of covariates. The spatiotemporal evolution of the entire Gulf of Corryvreckan system is sufficiently complex that the present GAM-GEE approach may struggle to adequately reflect this variability.

Ambient sound levels in tidal-stream habitats will vary at small spatiotemporal scales due to sediment transport, turbulent pressure fluctuations and entrainment of air bubbles through turbulence (Tonolla et al. 2010, Carter 2013). Given such spatiotemporal variability in ambient sound levels, the capabilities of passive acoustic detectors may not be constant across the tidal cycle. Drifters, in particular, often detected high and variable ambient noise levels, which could have reduced their detection capability to an unknown extent. Independent ambient noise measurements were not collected during this study, complicating an assessment of the impact of variable ambient sound levels on detector capabilities, an issue also affecting many other passive acoustic studies (Helble et al. 2013). Although porpoise echolocation rates were assumed to be constant in this study, specific circumstances of tidal-stream habitats could have led to changes in vocalisation behaviour which would have impacted detection patterns.

Much remains unclear about the underlying mechanisms driving top predator presence among tidal streams. Plankton have traditionally been assumed to become entrained within tidal structures, attracting fish and their predators such as harbour porpoises at particular tidal phases (the 'tidal coupling hypothesis'; Uda \& Ishino 1958, Wolanski \& Hamner 1988, Zamon 2002, 2003). However, cycles of prey behaviour and availability in these environments may be more important in attracting predators than absolute prey abundance (Zamon 2002). Small-scale ephemeral and tidally driven oceanographic fea- 
tures, such as shear boundaries, eddies and boils, are clearly important (Embling et al. 2013, De Boer et al. 2014, Jones et al. 2014), but the links between these small-scale features and the distribution, abundance and behaviour of both prey and top predators remain poorly understood (Benjamins et al. 2015). Little is presently known about porpoise prey selection within energetic environments, although a wide range of forage species are known to be targeted elsewhere in Scottish waters (Santos et al. 2004). Similarly, only limited information is available on how these fish species behave at tidal-stream sites. Although comparatively small fish $(<20 \mathrm{~cm})$ have been observed to maintain school cohesion at current speeds up to $2 \mathrm{~m} \mathrm{~s}^{-1}$ (Viehman \& Zydlewski 2015), faster flows and turbulent shear associated with tidal fronts and vortices rising from the seabed may disrupt the ability of fish to control their position, orientation and schooling behaviours. Opportunities for predators may therefore arise from fish being involuntarily displaced or disoriented. Concentrating foraging efforts at times and locations of increased prey vulnerability can significantly enhance predator foraging success (Quinn \& Cresswell 2004, Hopcraft et al. 2005, Crook \& Davoren 2014), and similar mechanisms may operate in tidal-stream habitats. Porpoise presence in tidal streams is likely driven by sitespecific circumstances at small spatiotemporal scales that should be considered when investigating potential interactions with human activities such as marine renewable energy extraction (Inger et al. 2009, Shields et al. 2011, Jones et al. 2014, Scott et al. 2014). Studying predator-prey relationships within energetic but tractable systems like the Great Race will offer further opportunities to assess the relative significance of prey availability vs. absolute prey abundance in determining foraging tactics for highly mobile marine predators such as harbour porpoises.

Acknowledgements. Support was provided by the UK Natural Environment Research Council (NERC) under grants NE/H009299/1 (Great Race Project) and NE/J004367/1 (RESPONSE), and by the Scottish Government, Highlands \& Islands Enterprise (HIE) and the European Regional Development Fund (ERDF) under the MaREE grant (RE011). We thank SAMS staff, particularly Jim Elliott, John Beaton and the crew of RV 'Calanus', for their help with mooring construction, deployment and recovery. Bathymetry data were kindly provided by Dr. John Howe (SAMS) through the EU INTERREG-funded 'INIS Hydro' project. Drifters were designed and constructed by Keith Jackson, Alistair James and Bernard Hagan (all SAMS) and deployed with the assistance of Seafari Marine Services. We also thank 3 anonymous reviewers for their constructive comments on this manuscript.

\section{LITERATURE CITED}

$\mathrm{Au}$ WWT, Hastings MC (2008) Principles of marine bioacoustics. Springer, New York, NY

Bailey H, Thompson P (2010) Effect of oceanographic features on fine-scale foraging movements of bottlenose dolphins. Mar Ecol Prog Ser 418:223-233

Bassett C, Thomson J, Polagye B (2010) Characteristics of underwater ambient noise at a proposed tidal energy site in Puget Sound. In: Martin D, Dahl P, Odom B, Cazzanti L, McGinnis T (eds) OCEANS 2010 Conference, Seattle, WA, 20-23 September 2010. Curran Associates, Red Hook, NY, p 2382-2389

Batchelor GK (2000) An introduction to fluid dynamics. Cambridge University Press, New York, NY

Benjamins S, Dale A, Hastie G, Waggitt JJ, Lea MA, Scott B, Wilson B (2015) Confusion reigns? A review of marine megafauna interactions with tidal-stream environments. Oceanogr Mar Biol Annu Rev 53:1-54

Booth CG (2016) Challenge of using passive acoustic monitoring in high-energy environments: UK tidal environments and other case studies. In: Popper AN, Hawkins A (eds) The effects of noise on aquatic life II. Springer, New York, NY, p 101-108

> Booth CG, Embling C, Gordon J, Calderan SV, Hammond PS (2013) Habitat preferences and distribution of the harbour porpoise Phocoena phocoena west of Scotland. Mar Ecol Prog Ser 478:273-285

> Carlström J (2005) Diel variation in echolocation behavior of wild harbor porpoises. Mar Mamm Sci 21:1-12

Carter CJ (2013) Mapping background underwater-sound in areas suitable for tidal-energy extraction in Scotland's coastal waters and the potential audibility of tidal-stream devices to marine mammals. $\mathrm{PhD}$ dissertation, University of the Highlands and Islands/University of Aberdeen, Inverness/Aberdeen

Castellote M, Leeney RH, O'Corry-Crowe G, Lauhakangas $\mathrm{R}$ and others (2013) Monitoring white whales (Delphinapterus leucas) with echolocation loggers. Polar Biol 36: 493-509

Chelonia Ltd (2015) Cetacean monitoring. Available at www. chelonia.co.uk/index.html (accessed 9 February 2015)

> Crook KA, Davoren GK (2014) Underwater behaviour of common murres foraging on capelin: influences of prey density and antipredator behaviour. Mar Ecol Prog Ser 501:279-290

Dähne M, Gilles A, Lucke K, Peschko V and others (2013) Effects of pile-driving on harbour porpoises (Phocoena phocoena) at the first offshore wind farm in Germany. Environ Res Lett 8:025002

> Dale AC, Boulcott P, Sherwin TJ (2011) Sedimentation patterns caused by scallop dredging in a physically dynamic environment. Mar Pollut Bull 62:2433-2441

Davies IM, Gubbins M, Watret R (2012) Scoping study for tidal-stream energy development in Scottish waters. Scottish Marine and Freshwater Science Report 3(1). Available at www.scotland.gov.uk/Publications/2012/04/ 2639 (accessed 23 October 2014)

> De Boer MN, Simmonds MP, Reijnders PJ, Aarts G (2014) The influence of topographic and dynamic cyclic variables on the distribution of small cetaceans in a shallow coastal system. PLoS One 9:e86331

Embling CB, Gillibrand PA, Gordon J, Shrimpton J, Stevick PT, Hammond PS (2010) Using habitat models to identify suitable sites for marine protected areas for harbour porpoises (Phocoena phocoena). Biol Conserv 143:267-279

Embling CB, Illian J, Armstrong E, Van der Kooij J, Sharples 
J, Camphuysen KCJ, Scott B (2012) Investigating finescale spatio-temporal predator-prey patterns in dynamic marine ecosystems: a functional data analysis approach. J Appl Ecol 49:481-492

Embling CB, Sharples J, Armstrong E, Palmer MR, Scott BE (2013) Fish behaviour in response to tidal variability and internal waves over a shelf sea bank. Prog Oceanogr 117: 106-117

> Fujiwara T, Nakata H, Nakatsuji K (1994) Tidal-jet and vortex-pair driving of the residual circulation in a tidal estuary. Cont Shelf Res 14:1025-1038

Gordon J, Macaulay J, Northridge S (2014) Tracking porpoise underwater movements in tidal rapids using drifting hydrophone arrays. Filling a key information gap for assessing collision risk. Paper EIMR2014-629 In: Proc 2nd Int Conf Env Interac MRE Tech (EIMR): EIMR, Stornoway, p 1-3

> Helble TA, Gerald LD, Campbell GS, Hildebrand JA (2013) Calibrating passive acoustic monitoring: correcting humpback whale call detections for site-specific and timedependent environmental characteristics. J Acoust Soc Am 134:EL400-EL406

- Hopcraft JGC, Sinclair ARE, Packer C (2005) Planning for success: Serengeti lions seek prey accessibility rather than abundance. J Anim Ecol 74:559-566

IJsseldijk LL, Camphuysen KC, Nauw JJ, Aarts G (2015) Going with the flow: tidal influence on the occurrence of the harbour porpoise (Phocoena phocoena) in the Marsdiep area. Neth J Sea Res 103:129-137

Inger R, Attrill MJ, Bearhop S, Broderick AC and others (2009) Marine renewable energy: potential benefits to biodiversity? An urgent call for research. J Appl Ecol 46:1145-1153

> Johnston DW, Thorne LH, Read AJ (2005a) Fin whales Balaenoptera physalus and minke whales Balaenoptera acutorostrata exploit a tidally driven island wake ecosystem in the Bay of Fundy. Mar Ecol Prog Ser 305:287-295

Johnston DW, Westgate AJ, Read AJ (2005b) Effects of finescale oceanographic features on the distribution and movements of harbour porpoises Phocoena phocoena in the Bay of Fundy. Mar Ecol Prog Ser 295:279-293

Joint Nature Conservation Committee (JNCC) (2014) Firth of Lorn designated Special Area of Conservation. Available at http://jncc.defra.gov.uk/ProtectedSites/SACselection/sac.asp?EUCode=UK0030041 (accessed 9 February 2015)

Jones AR, Hosegood P, Wynn RB, De Boer MN, ButlerCowdry S, Embling CB (2014) Fine-scale hydrodynamics influence the spatio-temporal distribution of harbour porpoises at a coastal hotspot. Prog Oceanogr 128:30-48

- Kumar S, Gupta R, Banerjee S (1998) An experimental investigation of the characteristics of free-surface turbulence in channel flow. Phys Fluids 10:437-456

Old C, Vennell R (2001) Acoustic Doppler current profiler measurements of the velocity field of an ebb tidal jet. J Geophys Res 106:7037-7049

> Otani S, Naito Y, Kato A, Kawamura A (2000) Diving behavior and swimming speed of a free-ranging harbor porpoise, Phocoena phocoena. Mar Mamm Sci 16:811-814

$>$ Otani S, Naito Y, Kato A, Kawamura A (2001) Oxygen consumption and swim speed of the harbor porpoise Phocoena phocoena. Fish Sci 67:894-898

Pierpoint C (2008) Harbour porpoise (Phocoena phocoena) foraging strategy at a high energy, near-shore site in south-west Wales, UK. J Mar Biol Assoc UK 88:1167-1173

Pirotta E, Matthiopoulos J, MacKenzie M, Scott-Hayward L, Rendell L (2011) Modelling sperm whale habitat preference: a novel approach combining transect and follow data. Mar Ecol Prog Ser 436:257-272
Quinn JL, Cresswell W (2004) Predator hunting behaviour and prey vulnerability. J Anim Ecol 73:143-154

Roberts BL, Read AJ (2015) Field assessment of C-POD performance in detecting echolocation click trains of bottlenose dolphins (Tursiops truncatus). Mar Mamm Sci 31: 169-190

> Santos MB, Pierce GJ, Learmonth JA (2004) Variability in the diet of harbor porpoises (Phocoena phocoena) in Scottish waters 1992-2003. Mar Mamm Sci 20:1-27

Scott BE, Langton R, Philpott E, Waggitt JJ (2014) Seabirds and marine renewables: Are we asking the right questions? In: Shields MA, Payne AIL (eds) Marine renewable energy and environmental interactions. Springer, Dordrecht, p 81-92

Shields MA, Woolf DK, Grist EP, Kerr SA and others (2011) Marine renewable energy: the ecological implications of altering the hydrodynamics of the marine environment. Ocean Coast Manag 54:2-9

Stevick PT, Incze LS, Kraus SD, Rosen S, Wolff N, Baukus A (2008) Trophic relationships and oceanography on and around a small offshore bank. Mar Ecol Prog Ser 363:15-28

> Stoesser T, Braun C, Garcia-Villalba M, Rodi W (2008) Turbulence structures in flow over two-dimensional dunes. J Hydraul Eng 134:42-55

> Tonolla D, Acuña V, Lorang MS, Heutschi K, Tockner K (2010) A field-based investigation to examine underwater soundscapes of five common river habitats. Hydrol Process 24:3146-3156

Uda M, Ishino M (1958) Enrichment pattern resulting from eddy systems in relation to fishing grounds. J Tokyo Univ Fish 1-2:105-119

UK Hydrographic Office (2008) Admiralty sailing directions. West Coast of Scotland Pilot, NP66, 16th edn. UKHO, Taunton

- Verfuß UK, Miller LA, Schnitzler HU (2005) Spatial orientation in echolocating harbour porpoises (Phocoena phocoena). J Exp Biol 208:3385-3394

> Viehman HA, Zydlewski GB (2015) Fish interactions with a commercial-scale tidal energy device in the natural environment. Estuar Coasts 38(Suppl 1):241-252

Wells MG, van Heijst GJF (2003) A model of tidal flushing of an estuary by dipole formation. Dyn Atmos Oceans 37:223-244

- Westgate AJ, Head AJ, Berggren P, Koopman HN, Gaskin DE (1995) Diving behaviour of harbour porpoises, Phocoena phocoena. Can J Fish Aquat Sci 52:1064-1073

Wilson B, Benjamins S, Elliott J, Gordon J, Macaulay J, Calderan S, van Geel N (2012) Estimates of collision risk of harbour porpoises and marine renewable energy devices at sites of high tidal-stream energy. Report prepared for the Scottish Government, Edinburgh. Available at www.gov.scot/Resource/0046/00462378.pdf (accessed 12 March 2015)

Wilson B, Benjamins S, Elliott J (2013) Using drifting passive echolocation loggers to study harbour porpoises in tidalstream habitats. Endang Species Res 22:125-143

Wolanski E, Hamner WM (1988) Topographically controlled fronts in the ocean and their biological influence. Science 241:177-181

Zamon JE (2002) Tidal changes in copepod abundance and maintenance of a summer Coscinodiscus bloom in the southern San Juan Channel, San Juan Islands, USA. Mar Ecol Prog Ser 226:193-210

Zamon JE (2003) Mixed species aggregations feeding upon herring and sandlance schools in a nearshore archipelago depend on flooding tidal currents. Mar Ecol Prog Ser 261:243-255

Zar JH (1999) Biostatistical analysis. Prentice-Hall International, Upper Saddle River, NJ 